Research Article

\title{
Total Business Management
}

\author{
Dr. Nasser Fegh-hi Farahmand
}

Department of Industrial Management, Tabriz Branch, Islamic Azad University, Tabriz, Iran

E-mail: farahmand@iaut.ac.ir, Mobile phone: 0098 - 914 - 1130172

\begin{abstract}
This paper describes the corporate-wide approach to Total Business Management (TBM) at organizations. TBM, referring to the internal systematic approach of the organization's management and leadership to strive for business performance excellence, and Total Business Policy (TBP) referring to all those measures through which one creates and strengthens confidence and trust in outsiders, especially customers, towards the organization's abilities and products. Naturally, TBP is a part of TBM. The paper reviews the strategy implementation, strategic control, business metrics, business channels and performance measurement literature to develop a conceptual model and research propositions. Current performance measurement guidelines are too generic for business managers and too reliant on financial measures.
\end{abstract}

Keywords: Total Business Management, Total Business Policy

\section{Introduction}

Recent research into business strategy implementation is damning in its findings. 'The reality is that traditional business implementation approaches have failed (Ambler\& et al, 2002, pp 12-19; Feghhi farahmand, 2002, pp 231-289; Collins\& et al, 1997, pp 669-689).

Business implementation is a critical link between formulation of business strategies and the achievement of superior organizational performance.

This paper focuses on the business strategy implementation strategies implemented in organizations. It is argued that globalization has resulted in rapid diffusion of high performance practices transforming business strategy implementation especially those organizations functioning in the international arena. By the same token, the use of different types of strategies in high performance organizations has become the commanding aspect of gaining competitive advantage for global companies.

Broadly, the utilization of various business strategy implementation strategies depends on the evaluation of content based and process based approaches during the formation process of strategic action. These approaches come up with planning and learning schools. Planning business strategy implementation which is leading the content based approach can be identified as the determination of clear cut behavioural actions in advance that results in successful organizational outcomes in the global marketplace. Whereas, business strategy implementation suggests the utilization of trial and error method for capturing the highly valued advantages that emerge along with the strategies implemented.

\section{Total Business Policy}

Strategic business science and business policies development is gaining increasing importance, both because of the realization of the central role of science and technology, which requires long-term investment, in economic and social development, and the need to manage scarce resources for optimal results over the long time span. (Dobni\& et al, 2001, pp. 400-408; Feghhi Farahmand, 2003, pp 111-160; Kumar and Subramanian, 1997/1998, pp. 107-124; Larson and Lusch, 1992, pp. 1-28; Fiegener, 1994, pp. 25-34).

Total Business Policy (TBP) foresight is a process, which assesses the potential of business policies from the technical standpoint, and from their broad social, economic and environmental implications (Feghhi farahmand, 2004, pp 20-40; Miles and Snow, 1978; Noble and Mokwa, 1999, pp. 57-73; Paswan, 2003, pp. 1941). It has been use as a tool for strategic management and planning and is gaining widespread acceptance.

\section{TBM understanding}

The problems of business participation have often been dealt with in the rich body of literature under the name public understanding of business science. 
To promote board involvement in TBM strategy, many have suggested that management needs to provide its directors with appropriate information and should develop appropriate educational and orientation programs to build and maintain their directors' skills and knowledge.

The focus of this study is on TBM specific processes meant to reduce information asymmetry, information management and director development and how they impact board involvement in strategy. When examining information management issues, focus is on two information characteristics the type of information and the access directors have to numerous sources of information.

In regards to director development issues, two board programs examined that aim to supporting director development of TBM orientation and education programs. By examining these issues, aim is contribute to the literature on governance by providing much needed empirical evidence on board functioning, particularly on information-related issues.

Furthermore, with most surveys reporting that directors still do not have appropriate information and knowledge to help them fulfil their emerging roles and responsibilities, aim is to provide guidance to organizations as they evaluate the informational and TBM needs of their directors. When examining these board processes, hypothesize is that because they reduce information asymmetry, more efficient information management and director development TBM programs would improve the board's involvement in strategy. These hypotheses can test through a survey of organization.

Findings generally confirmed that efforts towards improving information management systems and board development programs resulted in increased strategy involvement.

Rapid business advances have rampaged the way organizations respond to their changing circumstances. Consequently, organizational Total Business Management practices which enable high performance in light of these sophisticated businesses are becoming an essential part of an increasingly competitive global landscape.

Open source information systems that encourage organizational growth, learning and innovation of Total Business Management, along with human resource practices that model employee selection, managerial promotion mechanisms and performance evaluation processes pioneer the transformation of traditional processes into high performance practices.

Furthermore, team based organizational structures of Total Business Management bring expert knowledge from diverse fields together and the maximization of employee creativity results in new technologies and economic growth which are associated with some of the prominent characteristics of high performance Total Business Management for organizations.

The concept of TBM is broad and heterogeneous and needs some specification. We can distinguish between three layers of meaning for TBM (Stock\& et al, 1998, p 37; Feghhi farahmand, 2005, pp13-91; Yeniyurt, 2003, pp. 134-142):

1) In the meaning of ordinary language, TBM to the business person, beliefs, values or attitudes on science and business technology.

2) It refers to an ample field of businesslogical research on the business understandings of science and technology.

3) It refers to a broad spectrum of activities in business science education, communication, business technology assessment, and decision-making those are aimed at improving science business person relations.

In the first case there is a question of a relation between business, business persons and science, whereas the latter two cases refer to the research or activities that are focused on that business science relation. The model, describe the main variations in the latter two approaches and introduced by their main variables as:

- The general mission of TBM activities;

- The main research objects;

- The supposed main roles to be played by the business and business community.

The features of these models of TBM understanding are summarised in Table 1.

Table 1: Models of TBM understanding

\begin{tabular}{|c|c|c|c|}
\hline $\begin{array}{c}\text { Mission of } \\
\text { TBM }\end{array}$ & $\begin{array}{c}\text { Marketing model } \\
\text { education }\end{array}$ & $\begin{array}{c}\text { Favourable } \\
\text { conditions for } \\
\text { business scientific } \\
\text { development }\end{array}$ & $\begin{array}{c}\text { Total business } \\
\text { reflection on } \\
\text { favourable decision } \\
\text { making }\end{array}$ \\
\hline $\begin{array}{c}\text { Research } \\
\text { object }\end{array}$ & $\begin{array}{c}\text { Marketing level of } \\
\text { knowledge on } \\
\text { business }\end{array}$ & $\begin{array}{c}\text { Productive } \\
\text { strategies for } \\
\text { business science }\end{array}$ & $\begin{array}{c}\text { Constructions of } \\
\text { TBM } \\
\text { understandings }\end{array}$ \\
\hline $\begin{array}{c}\text { Role of } \\
\text { business }\end{array}$ & $\begin{array}{c}\text { Receiver of } \\
\text { marketing data }\end{array}$ & $\begin{array}{c}\text { Resource for } \\
\text { business } \\
\text { competitive }\end{array}$ & $\begin{array}{c}\text { Subject of TBM } \\
\text { empowerment }\end{array}$ \\
\hline
\end{tabular}


The starting point in the marketing model is the assumption of the business person's ignorance on the matters of business science and business technology. Since the business ignorance is generally interpreted as a lack or deficit of relevant information, central mission of TBM activities under the enlightenment model is to raise the educational level of the business. This may also be coupled with other marketing values such as providing business person's tools for cultural business understanding or tools for acting as full members of the modern scientific-technological society.

The business model shares with the marketing model the assumption of business person's ignorance and thus belongs to the category of deficit models. In the business model, however, the mission of TBM activities is economically instrumental.

They are taken as means for creating favourable conditions for business scientific development, and for increasing national prosperity. There are two assumptions underlying this idea:

a) Business person's acceptance of TBM is thought to be an important lubricator for modern business, and to be promoted by raising the overall level of business awareness of TBM.

b) Business persons with better knowledge of TBM are thought to be a valuable resource in the modern labour markets. Since the business informing attempts to improve acceptance of TBM, research under the business model is mainly focused on strategies for effective business science communication.

In general terms, both the business and the TBM community are interpreted as resources for the creation of competitive advantage under the business model.

TBM model is based on a questioning of both the assumption of total business ignorance and the main strivings expressed in the marketing and business models.

Instead of taking business persons ignorance as granted, the TBM model is interested in studying the various construction processes and functions of scientific and business technological knowledge in business person's understandings as well as in the TBM community. Central questions are:

a) How are the business understandings of business science and business technology constructed in local conditions?

b) What is the role of business scientific knowledge in respect to other types of knowledge?

c) What is the meaning of business science and business technology in everyday organizational life?

With these questions, the TBM approach resembles businesslogy of business scientific knowledge. Both approaches focus on the heterogeneous construction processes of business scientific practices.

\section{TBM approach}

The aim of TBM approach at organizations is to strive for the organization's strategic and operational goals. TBM based on a special expertise for enhancing Total Business Productivity (TBP) of business management and leadership.

High performance TBM contemplate on various types of strategies so as to capture highly valued competitive advantages in the global marketplace. From a behavioural perspective, organizations TBM formulate and use strategies over a wide range of alternatives which appear between pure deliberate and pure emerging ones.

In this vein, planned, entrepreneurial, ideological, umbrella, process, unconnected, consensus and imposed strategies can be utilized by different types of firms that strive for effective strategic choices related to their environmental conditions.

Additionally, content and process of TBM based strategies constitutively generate those strategic actions leading to successful outcomes. In fact, the pioneering element of high performance of TBM comes from the degree of compatibility between the two.

More specifically, the relationship between TBM strategy and strategy making exhibits that the process content dichotomy is an artefact of convenience and that the two are integral components of any organizational environment adaptation process, that is, of strategic management.

Thus, genuine realization of the TBM practices takes place in real business activities both in the organization's business strategic leadership as well as in the operational realization of the organization's business services and business targets. In this approach, all relevant interested businesspersons are also associated in accordance with their appropriate roles.

The goal of TBM, i.e. total business excellence, and reach through innovative business management and business leadership practices (Stock\& et al, 1998, p 37; Feghhi farahmand, 2005, pp13-91; Yeniyurt, 2003, pp. 134-142). In order to realize TBM objectives in all parts of the organization and at all levels of business and business management, an organization-wide management structure, a leadership infrastructure framework defined. The framework model as figure 1 originally created at organizations: 


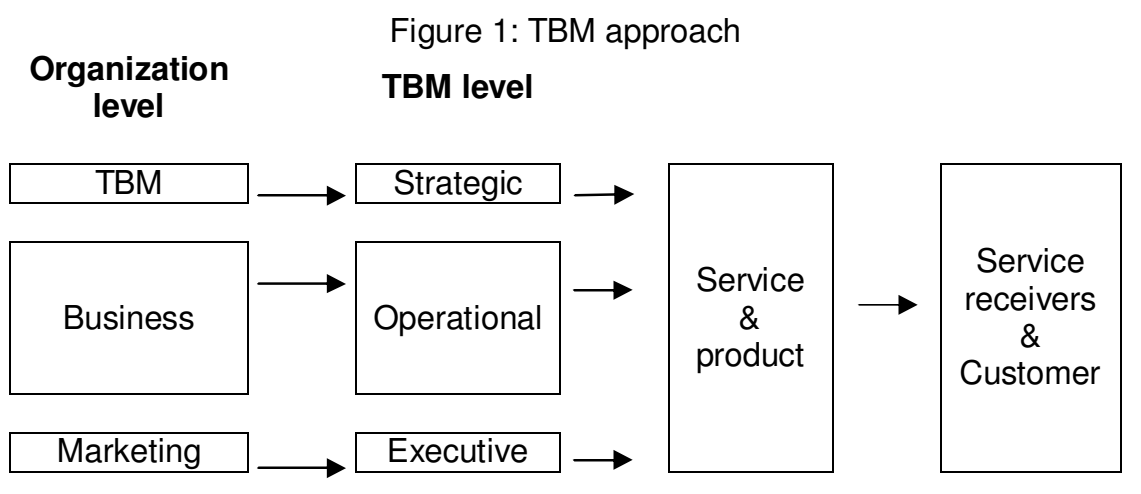

According to marketing strategy achieves competitive advantage through being the first into new markets with new products. It is innovative and adapts to new technology well. In contrast, the business achieves competitive advantage strategy by being more efficient. This means it does not have to be first into new markets with new products. Business strategies tend to have less product innovation than market strategist who aims to compete through innovative product or service features. The third of the generic strategies is the TBM strategy. This strategy combines elements of the marketing and business strategy.

As a result, the marketing and business strategy types have very contrasting human resource, organizational structure and most importantly for this paper, performance control guidelines The analyzer may be aggressive in some markets and defensive in others. It could see as an opportunistic strategy. This is because it attempts to seize the best opportunities. It does this even if this results in internal tensions or inconsistencies.

\section{Methodology}

Study of the future business likely to be important for business organizations has recently been undertaken. The Delphi method used to survey the opinions of more than 70 scientists and businessperson on the likely future importance of various businesses to the economic and business development. Participators in the business policy-making have become an important trend in many organizations and the need to the policy-making process identified as a business priority. Modern business has often been the topic of the first participatory experiments with scientists and business person.

High performance organizations can be characterized by their unique institutional peculiarities. TBM empowerment, along with a democratic management style plays a central role in the sustainability of high performing practices.

Some of the crucial attributes of these organizations include well balanced performance results, interesting goals that are clearly defined, committed and focused leadership, employees who are devoted to production and continuous learning, resources based on capabilities paving the way for competitive advantage and open communication-information management of TBM.

From this standpoint, top management teams ability to formulate effective TBM strategies and recognize novel work processes bring forth simple and flexible organizational structures.

The leadership features which encourage to think beyond the ordinary beliefs and to learn while adapting to rapid environmental changes are the key sources of high performance in the workplace. Although it is a generally hold idea that the possibilities for business participation should be increased, it is not an easy task. They are asking whether participatory decision-making really is a necessity, a realistic option or even a desirable trend.

\section{Result}

From an environmental perspective, the distinction between deliberate and emerging TBM strategies comes alive through the external interferences. Specifically, in the time of environmental pressures dictating patterns of organizational TBM action, pure emerging strategies derived from process perspective of strategy formulation, are implemented.

On the contrary, the absence of environmental disturbances gives way to intended and realized strategic actions which are associated with pure deliberate strategies founded on content perspective of strategy formulation.

This study certainly has managerial implications and should provide guidance to TBM organizations currently examining the functioning of their boards. Determining an appropriate information strategy that satisfies and balances the interests and needs of both management and directors is a challenging task. 
While directors may require more information, CEOs often fear that too much information can lead to undue interference.

Furthermore, merely providing more information is not the solution. TBM overload has been reported as a genuine problem that can divert directors' attention from important issues. Moreover, it is not the board's responsibility to micro-manage the company, and making unreasonable requests for information can be timeconsuming and create tensions with TBM management. Hopefully, these results will encourage dialogue between TBM management and directors to examine and evaluate their current TBM strategy. They need to examine whether the TBM they are providing is preventing directors to truly engage in strategy decisions. Furthermore, organizations prepared to provide TBM to their directors must also evaluate whether they have the ability to assimilate and comprehend this information.

Therefore, any TBM plan to provide directors with more information must be complemented with appropriate educational programs. Although this study enhances our knowledge of the challenges and consequences associated with decisions regarding information management and board development programs, the results obtained must be interpreted in the context of its limitations.

The study relies heavily on perceptual measures. However, getting access to the strategic and confidential information boards receive is TBM challenging; given the complex and sensitive nature of these issues, qualitative analyses can be particularly appropriate. Case studies would allow for a more thorough examination of board information and would make it possible to further our understanding of these issues.

Based on the above premises, the implementation of content and process based strategies in high performance organizations can be considered to have a strong relation with the characteristics of firms' task environment and the broader institutional field.

This model covers all marketing and business organization functions in a natural and flexible manner and covers the following three levels of the organization:

1) TBM level, where the general marketing and business principles the common insight, goals, shared tools, and practices concerning business are created, including how these principles are to be applied in practice on the basis of the organization's business requirements.

2) Business level, where the businesspersons the other top business leaders make marketing and business decisions, and measures undertaken concerning the entire particular business and especially the future competitiveness of the business and management of the whole business system addressed. The business system is composed of the interrelated operational business processes. Very often in organizations, there are different business areas that may be at different development stages. All these need different strategic TBM approaches but they may operate within one corporate culture.

3) Marketing level, where marketing decisions and measures concerning daily management made and undertaken, products and services realized in real time for customer needs.

\section{Conclusions}

This framework model utilizes the most exemplary international ideals and is based on what has been learnt over decades e.g. with business partners. In order to conceive how organization can make better use of high performance practices, top management teams should start by examining the institutional characteristics of the environment intact with the major sources of behavioural patterns.

The realization of organizational goals that are designed TBM in advance and emergence of organizational goals that unintentionally occur on its own accord may both dominate strategy formation during the distinctive phases embedded in an industry.

This study demonstrated that efforts to reduce information asymmetry through better TBM management and directors' development programs can translate into greater involvement in TBM strategy. The results from the analyses provided support for most hypotheses and valuable insights into these issues.

First, results about board TBM development activities suggest that investing in director development does affect board TBM strategy involvement.

Although the actual quality of director development programs has been questioned, study findings have shown that education programs can have a positive impact on TBM strategy involvement. These results probably reflect our strict characterization of educational programs: The construct used to characterize those programs includes best practices items such as the formal evaluation of director skills and the widespread participation of directors.

However, results regarding orientation programs were not significant. More information about the quality and depth of TBM programs may clearly be necessary to assess whether they can really contribute to superior board performance.

Second, results about TBM management generally indicate that efforts to provide directors with more information can have a positive effect on board TBM strategy involvement. They demonstrate that TBM has the potential to counter passive boards by further engaging directors in TBM strategy.

Increased types of information did not seem to enhance TBM strategy involvement. The non significant results found about the external information construct were somewhat surprising. Information about the industry 
such as its trends, its regulatory and technological environment and key competitors, constitutes strategic information on which are typically built strategic plans.

As such, TBM should be valuable for directors to truly evaluate the quality of the proposed strategies. These results may suggest that this type of information is more aligned with TBM strategy formulation and is considered to be management's domain.

TBM may be considered too general and too disconnected for directors to find useful. The performance TBM construct is mostly comprised of historical data, some of which subject to external auditing: Reports on financial performance, reports on operating performance, and information about the company's competitive positioning.

These results partly illustrate the potential limits and consequences that have been denounced by several authors.

Greater involvement in TBM strategy requires information that allows for better insight into the organizations' competitive position in the future.

Results about TBM greater access to a wider variety of informational sources indicate that efforts to establish communication channels with managers, employees or consultants can be beneficial. These results certainly validate requirements from some regulators to disclose how issues regarding directorial access to management and independent advisors are being addressed.

Study findings have globally shown the significant impact the type of information has on board behaviour and how management, through their information strategy, can shape their boards.

And, as such, this study's findings contribute to the literature on governance by providing relevant empirical evidence based on primary data on this complex topic.

Few studies have examined the actual impact of these information decisions on board behaviours. Another important contribution of this study is its detailed characterization of board information, drawing on insights derived from strategic process research.

Thus, appropriate strategy determination bringing about successful operation of business in high performance organizations is directly influenced by the contextual factors which cause deliberate and emerging TBM strategies to come into existence.

Effective implementing organization dedicated business integrated TBM does not call for any extra measures or investments. Experiences have proved that it is always worthwhile to improve the existing business management based on a systematic methodology. For TBM the organization must be always ready but never finished.

\section{References}

Ambler, T., Kokkinaki, F. and Puntoni, S. (2002) 'Assessing market performance: The current state of metrics', Working Paper No. 01-903, London Business School Centre of Business, London.

Andrews, K. R. (1987). The concept of corporate strategy, third edition. Homewood, IL: Irwin.

Ansoff, H. I. (1965). Corporate Strategy: An analytic approach to business policy for growth and expansion. New York: McGraw-Hill.

Ansoff, H. I. (1991). Critique of Henry Mintzberg's 'The design school: Reconsidering the basic premises of strategic management'. Strategic Management Journal, 12(6), 449-461.

Collins, F., Holzmann, O. and Mendoza, R. (1997) 'Strategy, budgeting, and crisis in Latin America', Accounting, Organisations and Society, Vol. 22, No. 7, pp. 669-689.

Cyert, R., March, J. G. (1963). A behavioral theory of the firm. Englewood Cliffs, NJ: Prentice Hall.

DiMaggio, P.J., Powell, W.W. (1991). The iron cage revisited: Institutional isomorphism and collective rationality. In W. W. Powell and P. J. DiMaggio (Ed.), The New Institutionalism in Organizational Analysis, (pp. 63-82) Chicago: University of Chicago Press.

Dobni, B., Dobni, D. and Luffman, G. (2001) 'Behavioural approaches to business strategy implementation', Business Intelligence \& Planning, Vol. 19, No. 6, pp. 400-408.

Evans, P., Wolf, B. (2005). Collaboration rules. Harvard Business Review. 83(7), 96-104.

Feghhi Farahmand, Nasser (2001), Executive Management Process, Islamic Azad University, Tabriz Branch, Iran, pp 21-123.

Feghhi Farahmand, Nasser (2003), Permanent Management of Organization, First edition, Frouzesh Publication, Tabriz, Iran, pp190-320.

Feghhi Farahmand, Nasser (2003), Strategic Structure of Organization Management Process, Forth edition, Islamic Azad University, Tabriz Branch, Iran, pp 110-125.

Feghhi Farahmand, Nasser (2005), Strategic Management of Organization, First edition, Frouzesh Publication, Tabriz, Iran, pp 95-144.

Feghhi Farahmand, Nasser (2009), Organization Strategic Plan compilation, First edition, Frouzesh Publication, Tabriz, Iran, pp 194-214.

Feghhi farahmand, Nasser (2011), Active and Dynamic Management of Organization, Second edition, Frouzesh Publication, Tabriz, Iran, pp 187-190. 
Feghhi Farahmand, Nasser (2011a), Technology Management of Organization, Second edition, Frouzesh Publication, Tabriz, Iran, pp 111-187.

Fiegener, M. K. (1994) 'Matching business-level strategic controls to strategy: Impact on control system effectiveness', Journal of Applied Business Research, Vol. 10, No. 1, pp. 25-34.

Fischer, B., Boynton, A. (2005). Virtuoso teams. Harvard Business Review. 83(7), 116-123.

Fleming, J.H., Coffman, C., Harter, J.K. (2005). Manage your human sigma. Harvard Business Review. 83(7): 106-114.

Florida, R., Goodnight, J. (2005). Managing for creativity. Harvard Business Review, 83(7), 124-131.

Josée Roy, Marie (2010), Building Director Involvement in Strategy The key Role of Information Processes, Faculty of Administrative Sciences, University Laval, Québec, Qc, Canada.

Katzenbach, J. R., Beckett, F., Dichter, S., Feigen, M., Gagnon, C., Hope, Q., Ling, T. (1996). Real change leaders. New York: Random House .

Katzenbach, J. R., Smith, D. K. (1993). The wisdom of teams: creating the high - performance organization. Boston, MA: Harvard Business School Press.

Kumar, K. and Subramanian, R. (1997/1998) 'Porter's strategic types: Differences in internal processes and their impact on performance', Journal of Applied Business Research, Vol. 14, No. 1, pp. 107-124.

Miles, R. E. and Snow, C. C. (1978) 'Organizational strategy, structure, and process', McGraw-Hill, New York.

Mintzberg, H. (1978). Patterns in strategy formation. Management Science, 24(9), 934-948.

Mintzberg, H. (1990). The design school: Reconsidering the basic premises of strategic management. Strategic Management Journal, 11(3), 171-195.

Mintzberg, H., McHugh, A. (1985). Strategy formation in an adhocracy. Administrative Science Quarterly, 30(2), 160-197.

Mintzberg, H., Waters, J. A. (1985). Of strategies, deliberate and emergent. Strategic Management Journal, 6(3), 257-272.

Mustafa M. Gökoğlu and Selcen Kılıçaslan (2009), Strategy Making in High Performance Organizations

Noble, C. H. and Mokwa, M. P. (1999) 'Implementing business strategies: Developing and testing a managerial theory', Journal of Business, Vol. 63, No. 4, pp. 57-73.

Osterman, P. (1999), Securing prosperity: The American labor market: how it has changed and what to do about it. Princeton: Princeton University Press.

Paswan, A. K. (2003) 'Channel support activities and perceived goal orientation: An exploration in the Indian market', Asia Pacific Journal of Business and Logistics, Vol. 15, No. 4, pp. 19-41.

Quinn, J. B. (1980). Strategies for change: Logical Incrementalism. Homewood, IL: Dow Jones-Irwin.

Quinn, R.E. (2005). Moments of greatness: Entering the fundamental state of leadership. Harvard Business Review, 83 (7), 74-83.

Segev, E. (1987). Strategy, strategy making and performance - An empirical investigation. Management Science, 33(2), 258-269.

Stock, G. N., Greis, N. P. and Kasarda, J. D. (1998) 'Logistics, strategy and structure A conceptual framework', International Journal of Operations \& Production Management, Vol. 18, No. 1-2, p 37.

Yang, S. (2008). Bureaucracy versus high performance: Work reorganization in the 1990s. The Journal of SocioEconomics, 37, 1825-1845.

Yeniyurt, S. (2003) 'A literature review and integrative performance measurement framework for multinational companies', Business Intelligence \& Planning, Vol. 21, No. 3, pp. 134-142. 